the difficulty of revising them expeditiously in the light of scientific and technical progress, experience gained and new epidemiological knowledge.

The United Nations World Health Organization was established in 1946, and in its constitution was given authority to adopt international sanitary regulations. Without delay, the Interim Commission of the Organization appointed expert committees to prepare a revision of existing sanitary conventions. They studied such questions as the sanitary control of the Mecca Pilgrimage, modern advances in epidemiology and methods of preventing transmission of disease by insect vectors. The technical documentation thus produced enabled the Expert Committee on International Epidemiology and Quarantine, with the help of its legal sub-committee, to prepare preliminary draft international sanitary regulations. In April-May 1951 these regulations were considered by the special committee appointed by the Third World Health Assembly at thirty-six plenary meetings held in the Palais des Nations, Geneva, under the chairmanship of Dr. M. T. Morgan (Great Britain). After receiving comments and suggestions from the delegates of the member States, a final draft was prepared which the special committee submitted to the Fourth World Health Assembly. The text of the Regulations was adopted unanimously on May 25, 1951, by the representatives of the sixty governments present ${ }^{2}$.

The first part of the official record of the International Sanitary Regulations consists of the proceedings of the special committer, appointed by the Third World Health Assembly, and of the plenary session of the Fourth World Health Assembly. The second part of the volume contains the text of the Regulations with an explanatory memorandum, a table of comparison between the provisions of the Regulations and those of previous sanitary conventions and similar agreements, and an index to the Regulations. The Regulations are a revision and a consolidation of the text of the numerous previous conventions and agreements; they came into force for all member States of the World Health Organization (and also for those non-member States which so signify) on October I, 1952.

Turning to the Regulations themselves, they are framed in the endeavour to secure maximum security against international spread of disease with minimum interference with world traffic. They revise and consolidate previous provisions on plague, cholera, yellow fever and typhus, including the Pan-American Sanitary Code, Havana, 1924. Relapsing fever, being suitable for control in ports, airports and at international frontiers, has been added. Supplementary regulations dealing with measures for preventing the spread of other epidemic diseases may be added from time to time, and already are envisaged as regards malaria.

It is required that the appearance of a quarantinable disease in a territory, and, if necessary, its continued existence, shall be notified to the Organization, which will report the information to all health administrations to which the Regulations apply. Thus health administrations will have a world-wide knowledge of the epidemiological situation of quarantinable diseases. In measures for the prevention of the importation of pestilential disease, it is intended that a State shall chiefly rely on its own public health service. The Regulations concerning plague, cholera, yellow fever, typhus and smallpox include all modern scientific methods of prevention. Vaccination is advised in the case of yellow fever; but not as regards typhus, because modern insecticides, properly applied, and disinfection where appropriate, afford adequate security. Rules governing the health control of the Mecca Pilgrimage have been added.

After reading the Regulations, including the procedure for acceptance, reservations and rejections, one obtains the impression that a great step forward has been made in the international control of epidemic disease. When all the governments of the world adopt the Regulations and implement them, they will protect not only their own frontiers from pestilence, but will also materially contribute to the health of all nations.

A. S. MacNalty

${ }^{1}$ MacNalty, Sir Arthur, Nature, 170, 108 (1952).

${ }^{2}$ World Health Organization. Official Records of the W.H.O., No. 37 International Sanitary Regulations; Proceedings of the Special Committee and of the Fourth World Health Assembly on WHO Regulations No. 2. Pp. iv +443 . (Geneva: World Health 2.25 dollars ; 9 Sw. franes.

\section{COPYRIGHT AND THE SCIENTIST}

$7 \mathrm{O}$ the scientific man, nurtured in the tradition of the greatest possible freedom for the circulation and interplay of new scientific knowledge, anything that tends to restrict that freedom is liable to be irksome. If the Copyright Act of 1911 was guilty of causing (or more accurately of perpetuating) uncertainty among the general public as to the extent to which published works might be reproduced, it is not surprising that it should have appeared to the scientific worker to be something of a maze, any tortuous path of which might lead him to wrongdoing. Apart from such general uneasiness, three specific factors have in recent years given added point to the problem. First, and probably the least troublesome, the growth in the use made of review literature has brought out the need for some clearer definition of the degree to which a work might be quoted without infringement of the "fair dealing" provisions of the Act. Secondly, the copious increase in scientific and technical literature during the present century has brought with it a corresponding need for digests and summaries for convenient record by the research worker. Thirdly, advances in photo-copying and microphotography have simplified the reproduction of tables of results, technical reports and periodical articles and virtually removed the principal "disincentive" to copying, namely, the laborious process of manual transcription. If the Report of the Copyright Committee* set up by Mr. Harold Wilson, then President of the Board of Trade, in April 1951 does not entirely resolve these problems, it does provide a reasoned commentary on them and its recommendations will doubtless form the basis of any new legislation that may be introduced.

It says much for the good sense of scholars, authors and publishers alike that no test case has so far been brought in British courts. Yet it is virtually certain that the law of copyright, as it now stands in relation to the limited copying permissible of any work "for the purpose of private study, research, criticism, review or newspaper summary" has been frequently infringed in the scientific field. The facts that, first, infringement has probably taken place either in ignorance of the law or from a lack of understanding * Report of the Copyright Committee, Cmd. 8562 . (London:
H.M.S.O. 4s. $6 d$. net.) 
of the conception of published work as property; secondly, that no author or publisher has yet felt able to seek issue at law ; and thirdly, that evidence of unlawful copying in cases of private study or research must be extremely difficult to obtain, only serve to emphasize that the present position is founded on fundamentally bad law. Two conflicting interests must be reconciled. On one hand, the scholar's interest demands that reasonable freedom to profit from the speed and cheapness of modern photographic methods of copying should be enjoyed, especially where original works are scarce or out of print. On the other, the author or his publisherneither of whom may be responsible in these days for a work going out of print-quite reasonably foresees that indiscriminate and cheap photographic copying may substantially affect his own income.

The Copyright Committee's diagnosis of this general problem is not at fault. What is debatable is whether the formula which it puts forward as machinery for the reconciliation of these two sets of interests rests upon a proper assessment of the nature of scientific communication. Broadly speaking, the Committee attempts to differentiate between the copying of periodical literature, books and manuscripts, a distinction of form rather than of content. The assumption is made-and for the purposes of science rightly made-that considerations of speed and currency lend the greatest importance to copying from periodical publications. Here it is proposed that, subject to certain statutory rules to be drawn up in consultation with organizations directly interested, any periodical literature should be available for copying. The minimum provisions of these rules which the Committee suggests is that copying should be done only by certain specified non-profit-making bodies, that the responsible librarian should satisfy himself that copies are genuinely required for private study or research, that one copy only of any one excerpt should be supplied to any one person and the excerpt restricted to one article, that the copy should not be supplied at less than cost price and that the applicant should give a written undertaking that the excerpt will not be used for other than its declared purpose. Apart from the question of designating the bodies under which such copying would be permitted, the proposals probably recognize, and are doubtless envisaged as giving force of law to, a procedure that is already not uncommonly adopted by learned societies and research libraries. Copying from books would be treated similarly except that the rules, since speed would not seem to be so essential, would enjoin some attempt to secure the author's or his publisher's permission before any "substantial" extract was copied.

It is not, however, sufficient to distinguish only between the various forms of printed publication. A more fundamental distinction lies between types of material published and, particularly, between works of creative imagination and papers or articles which bring scientific research data to public notice. While, on one hand, the author of a creative work expects to receive payment, and indiscriminafe copying would be against his interests, for the scientific man, on the other hand, publication is rarely a matter of commercial reward. 'The scientific man's financial return is often nil, or a merely nominal sum. His real profit is in the form of an increase in professional reputation. Indeed, his interest, like that of scientific progress, demands that his work should be circulated as widely and as freely as possible. Some such notion doubtless lies behind the common practice among learned journals of making reprints of their papers readily available to contributors; and since this indicates acceptance by a considerable body of publishers of the advantages of the system, it is difficult to sea that an extension of freedom to copy from scientific papers could do material harm. It should, of course, be required that every copy so made should bear a full reference to the original publication, and re-sale should be prohibited by law.

Needless to say, a general arrangement such as this would still be open to objections. Is it certain, for example, that works of creative imagination will not occasionally come near to being properly regarded as of scientific value? Is it reasonable to give the force of law to a permissive arrangement embodied in the Royal Society's "Fair Copying Declaration", and extend its application to all commercial scientific publishers in addition to those who have already accepted its provisions, together with many learned societies and other publishing agencies? How, if at all, would any general relaxation of copyright law in relation to scientific works affect British interests abroad under existing or contemplated international copyright conventions? Awkward as they are, it should not prove impossible to reach a fair solution of these problems. At the moment, it appears as though the Committee, in trying to please research worker, author and publisher alike and in treating all publication as a commercial investment, may have fallen into the trap of proposing statutory authority for a piece of cumbersome protective machinery which was created in self-defence against an anomalous and outmoded law.

LESLIE WILSON

\section{CHEMICAL RESEARCH LABORATORY, TEDDINGTON}

\section{REPORT FOR 1951}

A PUBLICATION bearing the general title "Chemistry Research 1951"* includes the report of the Chemistry Research Board, signed by the chairman, Prof. E. L. Hirst, and the report of the Chemical Research Laboratory, Teddington, over the signature of the director, Dr. D. D. Pratt, together with the customary lists of publications during the year, standard substances and staff, and an alphabetical list of species in the National Collection of Industrial Bacteria, which now includes more than five hundred strains. Following a special review by the Board of the research programme and distribution of effort in the Laboratory, increased effort has been assigned to the purification of organic compounds and the precise measurement of physical properties, and to the microbiological production of sulphur. Work on the precise measurement of the vapour pressures and boiling points of bases of the pyridine series has been resumed, and greater effort has been given to the chemical side of the joint programme with the Physics Division of the National Physical Laboratory on accurate bomb calorimetry. A team from the Chemical Research Laboratory is now using for the microbiological reduction of sulphate the continuous process developed by the Ministry of Supply's Experimental Station at Porton.

* Department of Scicntiflc and Industrial Research. Report of the Chemistry Research Board with the Report of the Director of the Chemical Research Laboratory for the Year 1951. Pp. iv $+126+4$ plates. (I.ondon: H.M. Stationery Office, 1952.) 48. 6d. net. 